Article

\title{
Thermo-Responsive Fluorescent Polymers with Diverse LCSTs for Ratiometric Temperature Sensing through FRET
}

\author{
Zhaoyang Ding ${ }^{+}\left(\mathbb{D}\right.$, Chunfei Wang ${ }^{\dagger}$, Gang Feng and Xuanjun Zhang *(1) \\ Faculty of Health Sciences, University of Macau, Macau SAR 999078, China; zhaoyangding@umac.mo (Z.D.); \\ yb67596@umac.mo (C.W.); yb67608@umac.mo (G.F.) \\ * Correspondence: xuanjunzhang@umac.mo; Tel.: +853-8822-4928 \\ + These authors contributed equally to this work.
}

Received: 30 January 2018; Accepted: 6 March 2018; Published: 8 March 2018

\begin{abstract}
Temperature is a significant parameter to regulate biological reactions and functions inside cells. Sensing the intracellular temperature with a competent method is necessary to understand life science. In this work, an energy-transfer polymeric thermometer was designed for temperature sensing. The thermometer was prepared from two thermo-responsive polymers with different lower critical solution temperatures (LCSTs) of $31.1{ }^{\circ} \mathrm{C}$ and $48.6{ }^{\circ} \mathrm{C}$, coupling with blue and red fluorescent molecules, respectively, developed for ratiometric temperature sensing based on the Förster resonance energy transfer (FRET) mechanism. The polymers were synthesized from two monomers, $\mathrm{N}$-isopropylacrylamide (NIPA) and $\mathrm{N}$-isopropylmethacrylamide (NIPmA), which provided different temperature responses. The fluorescent intensity of each polymer (peaked at 436 and $628 \mathrm{~nm}$, respectively) decreased upon the heating of the polymer aqueous solution. While these two polymer aqueous solutions were mixed, the fluorescent intensity decrease at $436 \mathrm{~nm}$ and substantial fluorescence enhancement at $628 \mathrm{~nm}$ was observed with the increasing temperature due to FRET effect. The cell imaging of HeLa cells by these thermo-responsive polymers was explored. The difference of LCSTs resulting in ratiometric fluorescence change would have a potential impact on the various biomedical applications.
\end{abstract}

Keywords: $\mathrm{N}$-isopropylacrylamide; $\mathrm{N}$-isopropylmethacrylamide; ratiometric temperature sensing; FRET

\section{Introduction}

Temperature is an essential physiological parameter during all biochemical reactions in living cells. It has a close relationship with cellular functions, such as cell division, gene expression, metabolism, enzyme reaction, and so on [1,2]. In addition, various abnormal medical phenomena, like cancer cell growth, are often accompanied by a temperature increase. Owing to these considerable demands, lots of promising approaches to fluorescent thermometers for cell temperature sensing have been studied [3]. Recently, many works have been developed for this requirement, including small organic dyes [4], quantum dots [5,6], polymers [7-11], and gold nanoclusters [12].

Nowadays, stimuli-responsive polymers have received more attentions for their potential biomedical applications. A variety of stimuli-responsive polymers whose properties change in response to temperature, $\mathrm{pH}$, ionic strength, light, and chemical stress have been investigated [13-17]. Thermo-responsive polymers have been applied in the fields of sensors, catalyst supports, drug carriers, and bio-separation [18-20]. Thermo-responsive polymers based on $\mathrm{N}$-isopropylacrylamide (NIPA) were the most common used in these years. These polymers have a lower critical solution temperature (LCST) close to human and most animal's physiological temperature, with good biocompatibility 
and low toxicity [21]. Many fluorophores [11,22,23] have already been introduced into NIPA-based polymers to visualize the temperature in living cells as fluorescent thermometer.

Fluorescent temperature sensing is usually based on the fluorescence intensity changes at certain wavelengths instead of fluorescence lifetime owing to its accessibility and prevalence. However, the fluorescence intensity at a single wavelength can be easily affected. Ratiometric fluorescent temperature sensing is more and more popular with potential advantages. For the ratiometric fluorescent temperature sensing based on the fluorescence resonance energy transfer (FRET) mechanism, multi-color fluorescence of NIPA-based polymer temperature sensors were reported [24-27]. In these studies, only one thermo-responsive monomer NIPA was used, which might limit the range of the temperature sensor. When a methyl group is added to NIPA, such as $\mathrm{N}$-isopropylmethacrylamide (NIPmA), the LCST of the NIPmA-based polymer was higher at around $45^{\circ} \mathrm{C}$ to $50^{\circ} \mathrm{C}[28,29]$. The introduction of NIPmA to the NIPA-based temperature sensing system is expected to enlarge the range of the temperature sensing, which should undergo a reversible LCST phase transition between the temperature range from $25^{\circ} \mathrm{C}$ to $50^{\circ} \mathrm{C}$. With the increasing of temperature, the shrink speed of the NIPA-based polymer was faster than the NIPmA-based polymer, leading to the distance change and FRET change between two polymers as shown in Scheme 1.

To test this hypothesis, we designed a NIPA-based polymer with blue fluorescence molecule (7-[4-(Trifluoromethyl)coumarin]methacrylamide) and a NIPmA-based polymer with red fluorescence molecule (BOBPYBX) synthesized by ourselves to form a novel polymeric ratiometric temperature sensor through FRET by the mixing of these two polymer solutions. We also characterized the effects of the temperature on their fluorescent behavior and exhibiting good performance both in aqueous solution and in the temperature imaging of cells.

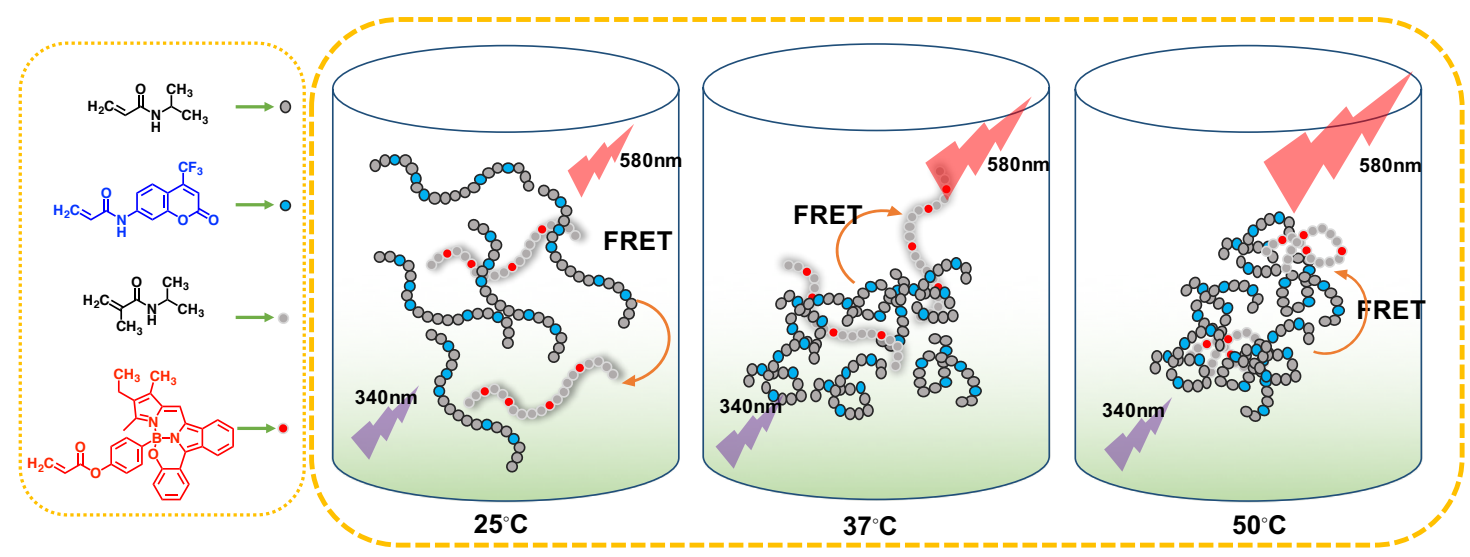

Scheme 1. Fabrication of two thermo-responsive fluorescent polymers with diverse LCSTs.

\section{Materials and Methods}

\subsection{Materials}

$\mathrm{N}$-isopropylacrylamide (NIPA), $\mathrm{N}$-isopropylmethacrylamide (NIPmA), 7-[4-(trifluoromethyl) coumarin]methacrylamide (TCMA), 2,2'-azobis(isobutyronitrile) (AIBN), 3-mercaptopropionic acid (MPA), 2-hydroxyphenyboronic acid, tetrakis(triphenylphosphine)palladium $\left(\mathrm{Pd}\left(\mathrm{PPh}_{3}\right)_{4}\right)$, Phosphorus(V) oxybromide $\left(\mathrm{POBr}_{3}\right)$ and phosphorus(V) oxychloride $\left(\mathrm{POCl}_{3}\right)$ were purchased from Sigma-Aldrich (St. Louis, MO, USA). 1-Isoindolinone, 2,4-dimethyl-3-ethylpyrrole, 4-hydroxyphenylboronic acid, acryloyl chloride, and triethylamine were purchased from Dieckman (Hong Kong) Chemical Industry Company Ltd. (Hong Kong, China). All other reagents and solvents were of analytical grade. 


\subsection{Synthetic of $B O B P Y B X$}

1 as presented in Scheme 2 was synthesized according to previous literatures with modification [30,31]. A solution of $\mathrm{POBr}_{3}(20 \mathrm{mmol}, 5.73 \mathrm{~g})$ in anhydrous dichloromethane $(5 \mathrm{~mL})$ was added dropwise to Dimethylformamide (DMF) $(20 \mathrm{mmol}, 1.46 \mathrm{~g})$ in anhydrous dichloromethane $(15 \mathrm{~mL})$ at $0{ }^{\circ} \mathrm{C}$. The mixture was stirred for $30 \mathrm{~min}$ at room temperature. Then a solution of 1-isoindolinone $(10 \mathrm{mmol}$, $1.33 \mathrm{~g}$ ) in anhydrous dichloromethane $(50 \mathrm{~mL})$ was added to the mixture at $0{ }^{\circ} \mathrm{C}$. Subsequently, the reaction mixture was heated at reflux for $6 \mathrm{~h}$. After cooling, the solvent was removed at reduced pressure. Ice water was added, and aqueous $\mathrm{NaOH}(5 \mathrm{M})$ was added the mixture to a $\mathrm{pH}$ of around 8. A black solid precipitated and the mixture was stirred overnight, then $\mathbf{1}$ (yield was $84.2 \%$ ) was collected by filtration.

2 as presented in Scheme 2 and BOBPYOH were synthesized by modifying previous method [32]. To 1 ( $8.00 \mathrm{mmol}, 2 \mathrm{~g})$, to 2-hydroxyphenyboronic acid (17.50 mmol, $2.41 \mathrm{~g})$ and $\mathrm{Pd}\left(\mathrm{PPh}_{3}\right)_{4}(0.25 \mathrm{mmol}$, $0.29 \mathrm{~g})$ aqueous $\mathrm{Na}_{2} \mathrm{CO}_{3}(1 \mathrm{M}, 20 \mathrm{~mL})$ and dry toluene $(50 \mathrm{~mL})$ were added in a Schlenk flask under nitrogen. This reaction mixture was then degassed via three freeze-pump-thaw cycles before filling with nitrogen again. The Schlenk flask was heated to $75^{\circ} \mathrm{C}$ for $24 \mathrm{~h}$. After cooling to room temperature, the reaction mixture was washed with water $(30 \mathrm{~mL} \times 3)$. Organic layers were combined, dried over anhydrous $\mathrm{Na}_{2} \mathrm{SO}_{4}$, and evaporated under vacuum. The crude product was refluxed for $3 \mathrm{~h}$ in ethanol $(120 \mathrm{~mL})$ containing aqueous $\mathrm{NaOH}(4 \mathrm{M}, 20 \mathrm{~mL})$. The solvent was removed in vacuum. The resultant solid was dissolved in ethyl acetate $(100 \mathrm{~mL})$, and neutralized with $\mathrm{HCl}(3 \mathrm{M})$. Organic layers were combined, dried under anhydrous $\mathrm{Na}_{2} \mathrm{SO}_{4}$, filtrated, and concentrated under vacuum, and the residual product was purified by silica gel column chromatography (dichloromethane/ethyl acetate $=1: 1$ ) to afford 2 (yield was $75.8 \%$ ). $\mathrm{POCl}_{3}(5.2 \mathrm{mmol}, 0.8 \mathrm{~g}$ ) was added to a dichloromethane solution $(15 \mathrm{~mL})$ of 2,4-dimethyl-3-ethylpyrrole $(10.4 \mathrm{mmol}, 1.28 \mathrm{~g})$ at $0{ }^{\circ} \mathrm{C}$. Then a solution of 2 $(5.2 \mathrm{mmol}, 1.23 \mathrm{~g})$ in dichloromethane $(25 \mathrm{~mL})$ was added dropwise to the reaction mixture at $0{ }^{\circ} \mathrm{C}$. The reaction mixture was stirred at room temperature for $4 \mathrm{~h}$. To this solution, 4-hydroxyphenylboronic acid ( $52 \mathrm{mmol}, 7.17 \mathrm{~g}$ ) was dissolved in THF and added. Then the reaction mixture was stirred for another $4 \mathrm{~h}$. After evaporation of the solvent, the residual product was purified by silica gel column chromatography (dichloromethane $/ n$-hexane $=10: 1$ ) to give BOBPYOH (yield was $72.3 \%$ ). NMR results of BOBPYOH were shown in Figures S1 and S2. ${ }^{1} \mathrm{H}$ NMR $\left(400 \mathrm{MHz}, \mathrm{CDCl}_{3}\right) \delta=8.12(\mathrm{~d}, J=8.2$, $1 \mathrm{H}), 7.97(\mathrm{dd}, J=7.9,1.5,1 \mathrm{H}), 7.88(\mathrm{~d}, J=8.1,1 \mathrm{H}), 7.47(\mathrm{t}, J=7.4,1 \mathrm{H}), 7.44-7.38(\mathrm{~m}, 2 \mathrm{H}), 7.34(\mathrm{~d}, J=7.2$, $2 \mathrm{H}), 7.04(\mathrm{~d}, J=8.4,2 \mathrm{H}), 7.00-6.94(\mathrm{~m}, 1 \mathrm{H}), 6.54-6.47(\mathrm{~m}, 2 \mathrm{H}), 2.46(\mathrm{~s}, 3 \mathrm{H}), 2.39(\mathrm{dd}, J=7.6,1.6,2 \mathrm{H})$, $2.27(\mathrm{~s}, 3 \mathrm{H}), 1.04(\mathrm{t}, J=7.6,3 \mathrm{H}) .{ }^{13} \mathrm{C}$ NMR $\left(101 \mathrm{MHz}, \mathrm{CDCl}_{3}\right) \delta=157.11,154.20,150.96,143.18,135.34$, 133.23, 133.00, 132.90, 132.10, 130.36, 128.77, 128.43, 126.35, 125.65, 125.38, 123.43, 120.13, 119.65, 119.57, $119.08,115.92,114.10,67.99,25.62,17.50,13.07,9.59$.

BOBPYBX was synthesized by modifying hydroxyl group with acryloyl chloride [33]. To a solution of BOBPYOH (2 mmol, $0.86 \mathrm{~g})$ and triethylamine $(3 \mathrm{mmol}, 0.3 \mathrm{~g})$ in dichloromethane $(20 \mathrm{~mL})$ acryloyl chloride $(20 \mathrm{mmol}, 1.8 \mathrm{~g})$ was added slowly and stirred for $0.5 \mathrm{~h}$ at $0{ }^{\circ} \mathrm{C}$. Then the reaction was stirred further at room temperature for $12 \mathrm{~h}$. The mixture was treated with water and the organic layer was separated. The aqueous layer was extracted with dichloromethane and the combined organic layer was washed with saturated aqueous $\mathrm{NH}_{4} \mathrm{Cl}$, brine, and dried over anhydrous $\mathrm{Na}_{2} \mathrm{SO}_{4}$. The solvent was removed by rotary evaporation and the residue was purified by silica gel column chromatography (dichloromethane $/ n$-hexane $=10: 1$ ) to afford BOBPYBX (yield was 35.5\%). NMR results of BOBPYBX were shown in Figures S3 and S4. ${ }^{1} \mathrm{H}$ NMR $\left(400 \mathrm{MHz}, \mathrm{CDCl}_{3}\right) \delta=8.12(\mathrm{~d}, J=8.2,1 \mathrm{H}), 7.97(\mathrm{dd}, J=7.9$, $1.5,1 \mathrm{H}), 7.89(\mathrm{~d}, J=8.1,1 \mathrm{H}), 7.48(\mathrm{t}, J=7.5,1 \mathrm{H}), 7.44-7.38(\mathrm{~m}, 2 \mathrm{H}), 7.34(\mathrm{dd}, J=11.2,4.0,1 \mathrm{H}), 7.28(\mathrm{~d}$, $J=0.9,1 \mathrm{H}), 7.20(\mathrm{~d}, J=8.4,2 \mathrm{H}), 7.02-6.93(\mathrm{~m}, 1 \mathrm{H}), 6.83-6.73(\mathrm{~m}, 2 \mathrm{H}), 6.48(\mathrm{dd}, J=17.3,1.4,1 \mathrm{H}), 6.22$ $(\mathrm{dd}, J=17.3,10.4,1 \mathrm{H}), 5.90(\mathrm{dd}, J=10.4,1.4,1 \mathrm{H}), 2.47(\mathrm{~s}, 3 \mathrm{H}), 2.39(\mathrm{tt}, J=9.2,4.5,2 \mathrm{H}), 2.27(\mathrm{~s}, 3 \mathrm{H}), 1.05$ $(\mathrm{t}, J=7.6,3 \mathrm{H}) .{ }^{13} \mathrm{C}$ NMR $\left(101 \mathrm{MHz}, \mathrm{CDCl}_{3}\right) \delta=164.68,156.91,151.01,149.31,143.29,135.33,133.43$, $133.09,132.66,132.03,131.94,130.46,128.74,128.55,128.24,126.39,125.67,125.47,123.47,120.14,119.86$, $119.81,119.60,119.07,115.97,17.48,14.84,13.05,9.59$. 


\subsection{Synthesis of Fluorescent Polymers}

Two thermo-responsive polymers were named from the monomers, $\mathrm{P}_{\mathrm{NB}}$ consisted of NIPA and TCMA, and $\mathrm{P}_{\mathrm{NmR}}$ was NIPmA and BOBPBYX. $\mathrm{P}_{\mathrm{NB}}$ was prepared using radical polymerization, as shown in Scheme 2. NIPA (1.58 g, $14 \mathrm{mmol})$ and TCMA $(4.3 \mathrm{mg}, 0.015 \mathrm{mmol})$ were dissolved in ethanol $(20 \mathrm{~mL})$. AIBN (10 mg, $0.06 \mathrm{mmol})$ and MPA $(50 \mathrm{mg}, 0.5 \mathrm{mmol})$, which act as the radical initiator and the chain transfer agent to control the molecular weight of the polymers, respectively, were added to the solution. The reaction mixture was degassed and reacted in a $\mathrm{N}_{2}$ atmosphere at $65^{\circ} \mathrm{C}$ for $12 \mathrm{~h}$. After the reaction finished, the solvent ethanol was removed by a vacuum dryer and the product was precipitated by $n$-hexane and washed with acetone three times. The solid product was dried under vacuum conditions. The molecular weight of the polymer was determined by gel permeation chromatography (GPC) analysis. $\mathrm{P}_{\mathrm{NmR}}$ was prepared from NIPmA and BOBPYBX, which was synthesized by ourselves as shown in Scheme 2, according to the above procedure.

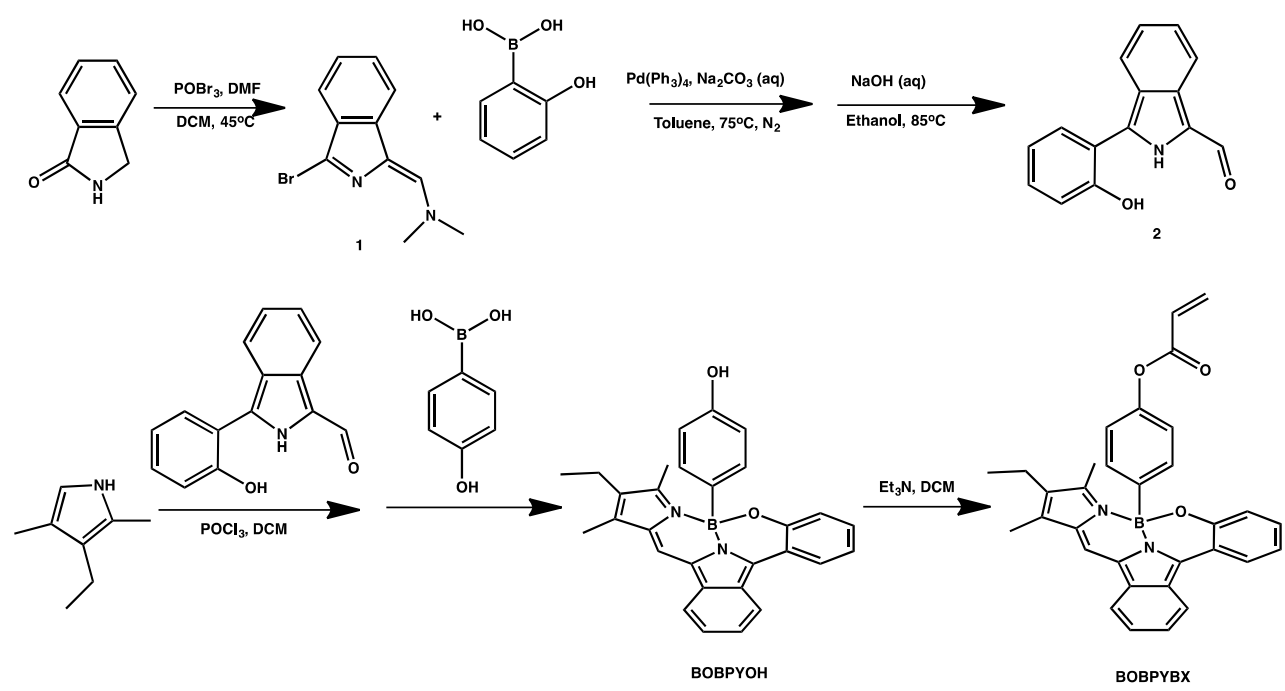

Scheme 2. Synthetic procedure of BOBPYBX.

\subsection{Analytical Techniques}

GPC was conducted on a Cirrus system (PL-GPC 50, Santa Clara, CA, USA) equipped with a differential refractive index detector. DMF was used as the eluent with a gel column $\left(300 \times 650 \mathrm{~mm}^{2}\right)$ (at $40{ }^{\circ} \mathrm{C}$, the flow rate $=1 \mathrm{~mL} / \mathrm{min}$ ). A Fourier transform infrared spectrometer (FTIR, IRAffinity-1S, Shimadzu, Japan) was used to determinate the structures of the fluorescent polymers. For each sample, each spectrum was obtained by 32 scans with the wavenumber ranging from 400 to $4000 \mathrm{~cm}^{-1}$ and resolution was $4 \mathrm{~cm}^{-1}$.

LCSTs of the polymers were determined by measuring the optical transmittance of their aqueous solution $(0.5 \% w / v)$. A sample cell with a $1 \mathrm{~cm}$ path length was used to measure the transmittance using $500 \mathrm{~nm}$ over a range of temperatures from 25 to $50{ }^{\circ} \mathrm{C}$ using a UV-Vis spectrophotometer (Shimadzu UV-3600 spectrophotometer, Shimadzu, Japan). The temperature at which the transmittance decreased to half of its initial value was taken as the LCST [34]. Fluorescence spectra (Fluorolg-4 spectrofluorometric) with a temperature controller were performed for the experiments. A quartz cuvette with a $1 \mathrm{~cm}$ path length was used. The maximum excitation wavelengths of the fluorescent polymers were as follows $\left(0.5 \% w / v\right.$ aqueous solution): $\mathrm{P}_{\mathrm{NB}} \lambda \mathrm{ex}=340 \mathrm{~nm} ; \mathrm{P}_{\mathrm{NmR}} \lambda \mathrm{ex}=580 \mathrm{~nm} ; \mathrm{P}_{\mathrm{MIX}}$ $\lambda \mathrm{ex}=340 \mathrm{~nm}$. The effects temperature on the fluorescence intensity of the polymers were evaluated between 25 and $50{ }^{\circ} \mathrm{C}$. 


\subsection{Cell Culture}

The cervical cancer line HeLa cells were kindly provided by Faculty of Health Sciences, University of Macau. HeLa cells were incubated in DMED (Dubecco's Modified Eagle Medium) medium supplemented with $10 \%$ FBS (fetal bovine serum) and 1\% penicillin-streptomycin solution. All cells were maintained at $37{ }^{\circ} \mathrm{C}$, in a $5 \% \mathrm{CO}_{2}$ humidified environment.

HeLa cells were seeded into glass-bottomed culture dishes and allowed to adhere for $24 \mathrm{~h}$. After removing the medium, $10 \mu \mathrm{M}$ polymer solution was added and incubated for $1 \mathrm{~h}$ at $37^{\circ} \mathrm{C}$. After the incubation, cells were washed twice by pre-warmed PBS buffer. Fixative solution (Histochoice ${ }^{\circledR} \mathrm{Mb}$ Tissue Fixative, Amresco, Dallas, TX, USA) was added for $15 \mathrm{~min}$ at room temperature, then washed three with PBS buffer. The samples were observed by Carl Zeiss Confocal LSM710 at $25^{\circ} \mathrm{C}$ or $37^{\circ} \mathrm{C}$.

\section{Results and Discussion}

Two fluorescent polymers were synthesized via radical polymerization. The synthetic scheme and structures of the polymers are shown in Scheme 3. For these two polymers, NIPA and NIPmA, were selected as the backbone of the thermo-responsive fluorescent polymers, to ensure the polymers having enough thermo-responsibility and water-solubility, the NIPA or NIPmA units in polymers were controlled above $98 \mathrm{~mol} \%$ and less than $1 \mathrm{~mol} \%$ of the fluorescent monomers were introduced into the polymers. 7-[4-(Trifluoromethyl)coumarin]methacrylamide (blue) and newly-synthesized BOBPYBX (red) were chosen as fluorescent monomers to form the FRET system. The polymers undergo reversible LCSTs phase transition between the temperature range from $25^{\circ} \mathrm{C}$ to $50^{\circ} \mathrm{C}$, which covers the physiological temperature of humans and most animals.
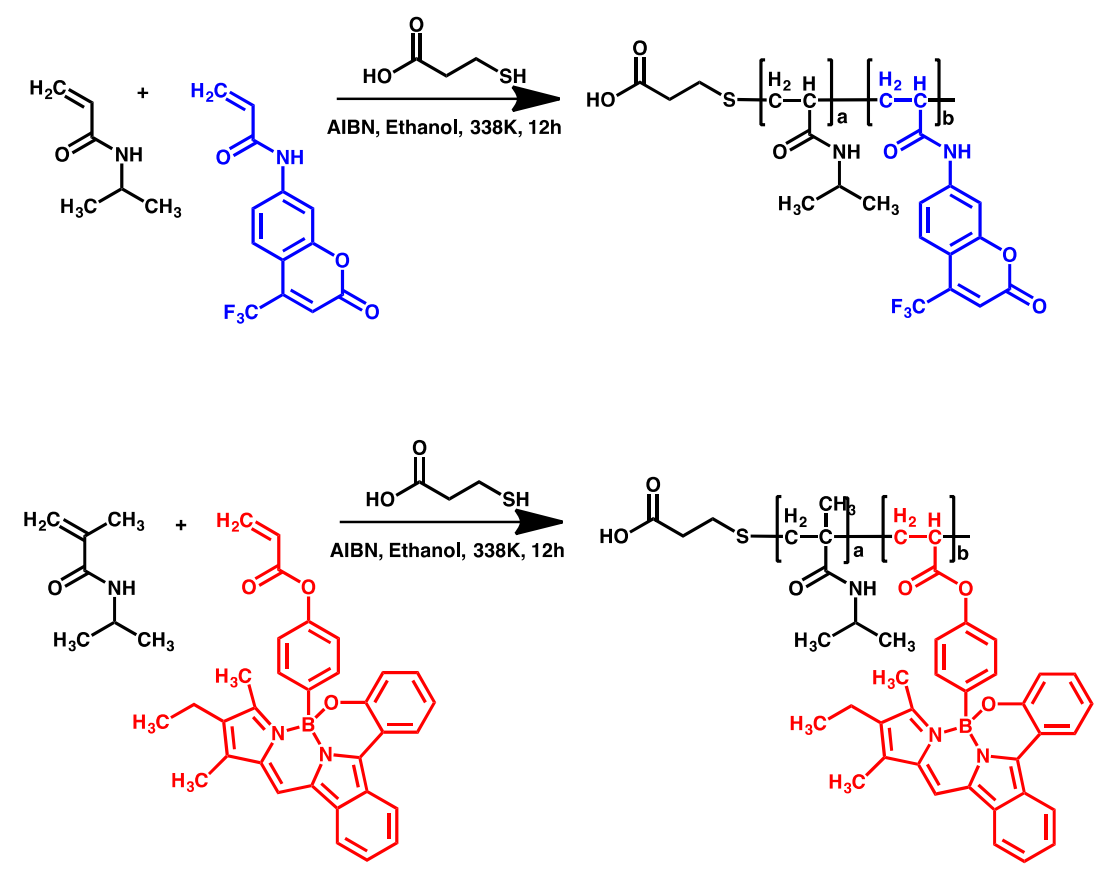

Scheme 3. Syntheses of fluorescent polymers.

The successful synthesis of fluorescent polymers was confirmed by FT-IR and absorption measurement as shown in Figure 1. According to the results, the maximum absorption peaks of $\mathrm{P}_{\mathrm{NB}}$ and $\mathrm{P}_{\mathrm{NmR}}$ were $340 \mathrm{~nm}$ and $620 \mathrm{~nm}$, respectively. The LCSTs of $\mathrm{P}_{\mathrm{NB}}$ and $\mathrm{P}_{\mathrm{NmR}}$ were $31.1{ }^{\circ} \mathrm{C}$ and $48.6^{\circ} \mathrm{C}$, which were as expected. The FTIR spectrum of $\mathrm{P}_{\mathrm{NB}}$ featured the characteristic absorption peaks at 3300-3090 $\mathrm{cm}^{-1}$ (secondary amine group), $2980 \mathrm{~cm}^{-1}$ (methyl group), $2900 \mathrm{~cm}^{-1}$ (methylene group), and $1180-1130 \mathrm{~cm}^{-1}$ (trifluoromethyl group), which are attributable to the two monomers. This strongly indicates the successful formation of polymer $P_{N B}$. The FT-IR spectrum of $P_{N m R}$ also 
exhibited the similar result. The fluorescent monomer ratio was so small that did not show very typical peaks in the FT-IR results, however, the absorption spectrum and fluorescent spectrum proved the polymerization was successful. The results of number-averaged and weight-averaged molecular weights were determined by gel permeation chromatography (GPC), as shown in Table 1 and Figures S5 and S6. The oligomeric products were obtained due to the use of chain-transfer agent.
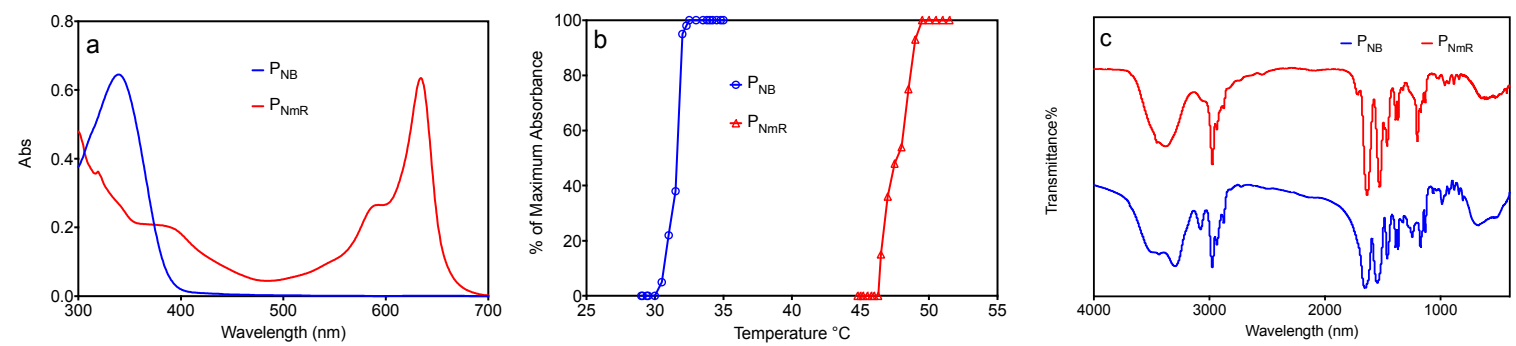

Figure 1. Characterization of fluorescent polymers. (a) Absorption spectra of the fluorescent polymers; (b) temperature-dependent for the fluorescent polymers in aqueous solution (500 nm, $0.5 \% \mathrm{w} / \mathrm{v})$; and (c) FT-IR results of the fluorescent polymers.

Table 1. GPC results of fluorescent polymers.

\begin{tabular}{cccc}
\hline Polymers & $\boldsymbol{M}_{\mathbf{n}}$ & $\boldsymbol{M}_{\mathbf{w}}$ & PDI \\
\hline $\mathrm{P}_{\mathrm{NB}}$ & 5957 & 7954 & 1.33121 \\
$\mathrm{P}_{\mathrm{NmR}}$ & 11,144 & 16,140 & 1.44831
\end{tabular}

$M_{\mathrm{W}}$ : weight average molecular weight; $M_{\mathrm{n}}$ : number average molecular weight; PDI: Polymer dispersity index, $\mathrm{PDI}=M_{\mathrm{w}} / M_{\mathrm{n}}$

We then investigated the temperature response behavior of the fluorescent polymers. The temperature-dependent fluorescence spectra and optical transmittance of $\mathrm{P}_{\mathrm{NB}}$ in aqueous solution are shown in Figure 2a. The fluorescent intensity of $\mathrm{P}_{\mathrm{NB}}$ was found to decrease with increasing of the temperature from $25{ }^{\circ} \mathrm{C}$ to $50{ }^{\circ} \mathrm{C}$, and the polymer $\mathrm{P}_{\mathrm{NmR}}$ showed the similar phenomenon as in Figure $2 b$. As shown in Figure 2d,e, the fluorescent intensity of both $\mathrm{P}_{\mathrm{NB}}$ and $\mathrm{P}_{\mathrm{NmR}}$ had the liner relationship with the temperature from $30{ }^{\circ} \mathrm{C}$ to $50{ }^{\circ} \mathrm{C}$. Hydrate form and swollen state of the thermo-responsive polymers were driven by their native properties. The fluorescent monomer displayed higher emission quantum yield in polar media, resulting in the stronger fluorescence intensity with the increase of the temperature. We could, therefore, conclude that the fluorescent intensity responses of these polymers were driven by a combination of the properties of both thermo-responsive monomers and the fluorescent monomers. The LCSTs of $\mathrm{P}_{\mathrm{NB}}$ and $\mathrm{P}_{\mathrm{NmR}}$ were 31.1 and $48.6{ }^{\circ} \mathrm{C}$, respectively. Due to these results, ratiometric fluorescent temperature sensing through FRET which is very powerful in analysis and sensing can be achieved by mixing these two polymers, especially between their two LCSTs. We tried several ratios of mixed $\mathrm{P}_{\mathrm{NB}}$ and $\mathrm{P}_{\mathrm{NmR}}$, and the final ratio of $P_{N B}$ and $P_{N m R}$ was set as 20:1. The fluorescence response results were indicated in Figure 2c, a dramatic fluorescence decrease at $436 \mathrm{~nm}$ and substantial fluorescence enhancement at $628 \mathrm{~nm}$ was observed upon heating. However, the fluorescence enhancement of $P_{\mathrm{NmR}}$ was limited in comparison with the result in Figure $2 \mathrm{~b}$. The ratio of fluorescent intensity F628 nm/F436 nm had liner relationship with temperature between two LCSTs as shown in Figure 2f. With the increasing of temperature, the shrink speed of $\mathrm{P}_{\mathrm{NB}}$ was faster than $\mathrm{P}_{\mathrm{NmR}}$, leading to the distance change and FRET change between two polymers. The shrink changes and fluorescence changes of the polymers to different temperatures could be directly visualized by the naked eye, and the fluorescence was excited by the light of hand-held UV lamp at $365 \mathrm{~nm}$. For $\mathrm{P}_{\mathrm{NB}}$ shown in Figure $2 \mathrm{~g}$, the polymer solution became turbid from $25^{\circ} \mathrm{C}$ to $37^{\circ} \mathrm{C}$ and $50^{\circ} \mathrm{C}$, and the fluorescence were all blue emissions. In Figure $2 \mathrm{~h}, \mathrm{P}_{\mathrm{NmR}}$ solution was clear at $25^{\circ} \mathrm{C}$ and $37^{\circ} \mathrm{C}$, turbid when at $50^{\circ} \mathrm{C}$ which was above the 
LCST of it and the $\mathrm{P}_{\mathrm{NmR}}$ solution exhibited dark red emission. $\mathrm{P}_{\mathrm{MIX}}$ exhibited purple emission at $25^{\circ} \mathrm{C}$, pink and bright pink emission at $37^{\circ} \mathrm{C}$ and $50{ }^{\circ} \mathrm{C}$ due to FRET effects, as shown in Figure $2 \mathrm{i}$. In the meantime, the $\mathrm{P}_{\mathrm{MIX}}$ solution became turbid from $25^{\circ} \mathrm{C}$ to $37^{\circ} \mathrm{C}$ and $50{ }^{\circ} \mathrm{C}$.
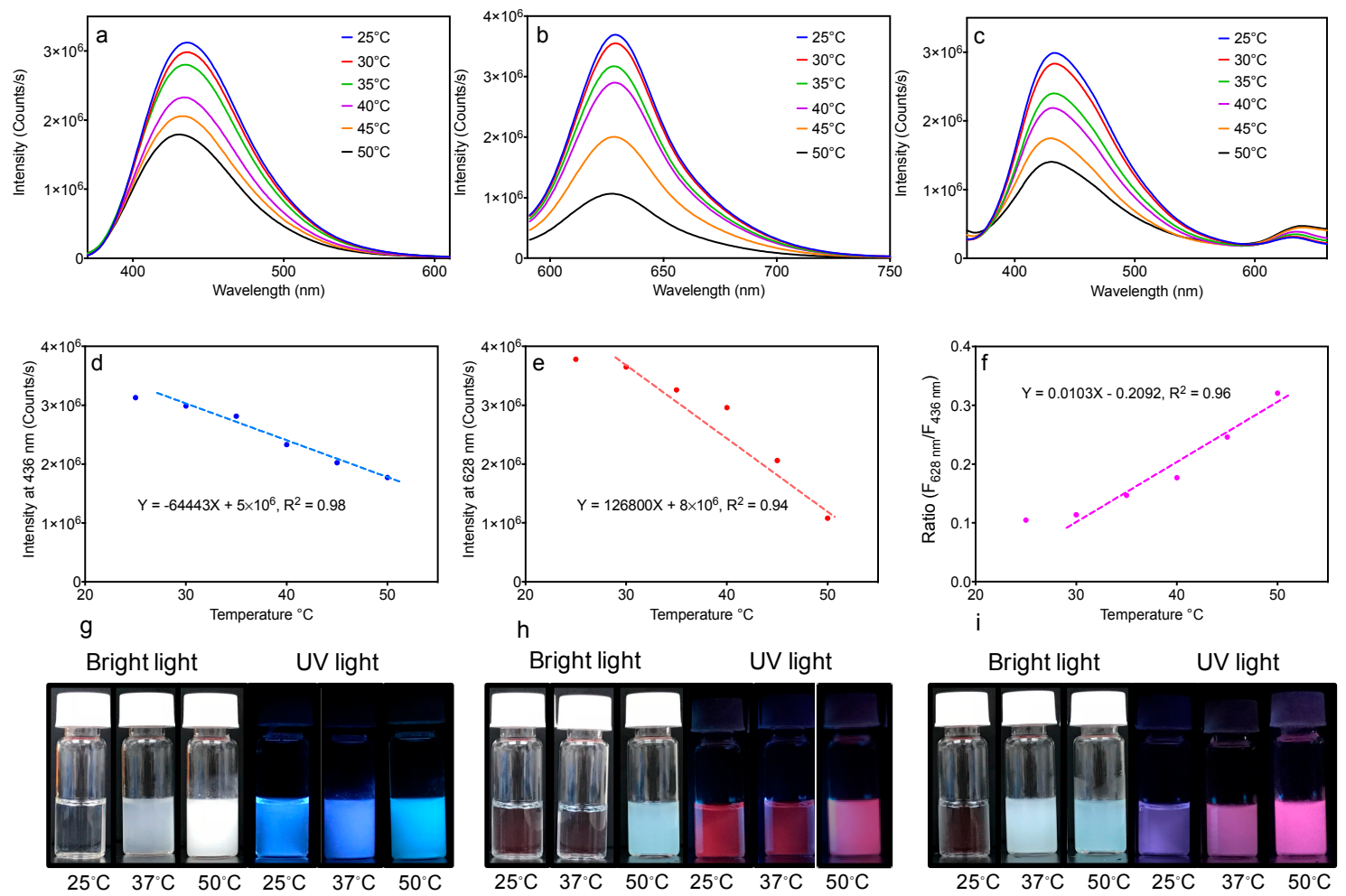

Figure 2. Fluorescence responses of polymers to temperature from $25{ }^{\circ} \mathrm{C}$ to $50{ }^{\circ} \mathrm{C}$. (a) Fluorescence spectra of $\mathrm{P}_{\mathrm{NB}}$ upon temperature $25{ }^{\circ} \mathrm{C}$ to $50{ }^{\circ} \mathrm{C}$; (b) fluorescence spectra of $\mathrm{P}_{\mathrm{NmR}}$ upon temperature $25{ }^{\circ} \mathrm{C}$ to $50{ }^{\circ} \mathrm{C}$; (c) fluorescence spectra of $\mathrm{P}_{\mathrm{MIX}}$ upon temperature $25^{\circ} \mathrm{C}$ to $50{ }^{\circ} \mathrm{C}$; (d) Linear correlation of $\mathrm{P}_{\mathrm{NB}}$ between the emission intensity at $436 \mathrm{~nm}$ and temperature; (e) linear correlation of $\mathrm{P}_{\mathrm{NmR}}$ between the emission intensity at $628 \mathrm{~nm}$ and temperature; (f) linear correlation of $\mathrm{P}_{\text {MIX }}$ between the emission intensity (F628 nm/F436 nm) and temperature; (g-i) naked eye photographs of the fluorescence change of the polymers $\mathrm{P}_{\mathrm{NB}}, \mathrm{P}_{\mathrm{NmR}}$, and $\mathrm{P}_{\mathrm{MIX}}$ in aqueous solution $(0.5 \% w / v)$ at different temperatures, respectively.

In view of the significance of temperature on the biological events within living cells, fluorescent images of HeLa cells incubated with polymers were explored. Figure 3 a showed blue emission of cells based on the uptake of $\mathrm{P}_{\mathrm{NB}}$ and Figure $3 \mathrm{~b}$ showed a red emission of cells because of the uptake of $\mathrm{P}_{\mathrm{NmR}}$. When the cells were incubated with $\mathrm{P}_{\mathrm{MIX}}$, both blue and red emissions were observed as shown in Figure $3 c, d$, and the merge picture showed pink emission. Figure $3 c$ had stronger blue emission and weaker red emission compared with Figure $3 \mathrm{~d}$ due to the change of observing temperature from $25^{\circ} \mathrm{C}$ to $37^{\circ} \mathrm{C}$. The results were consistent with previous fluorescent spectrum data. 


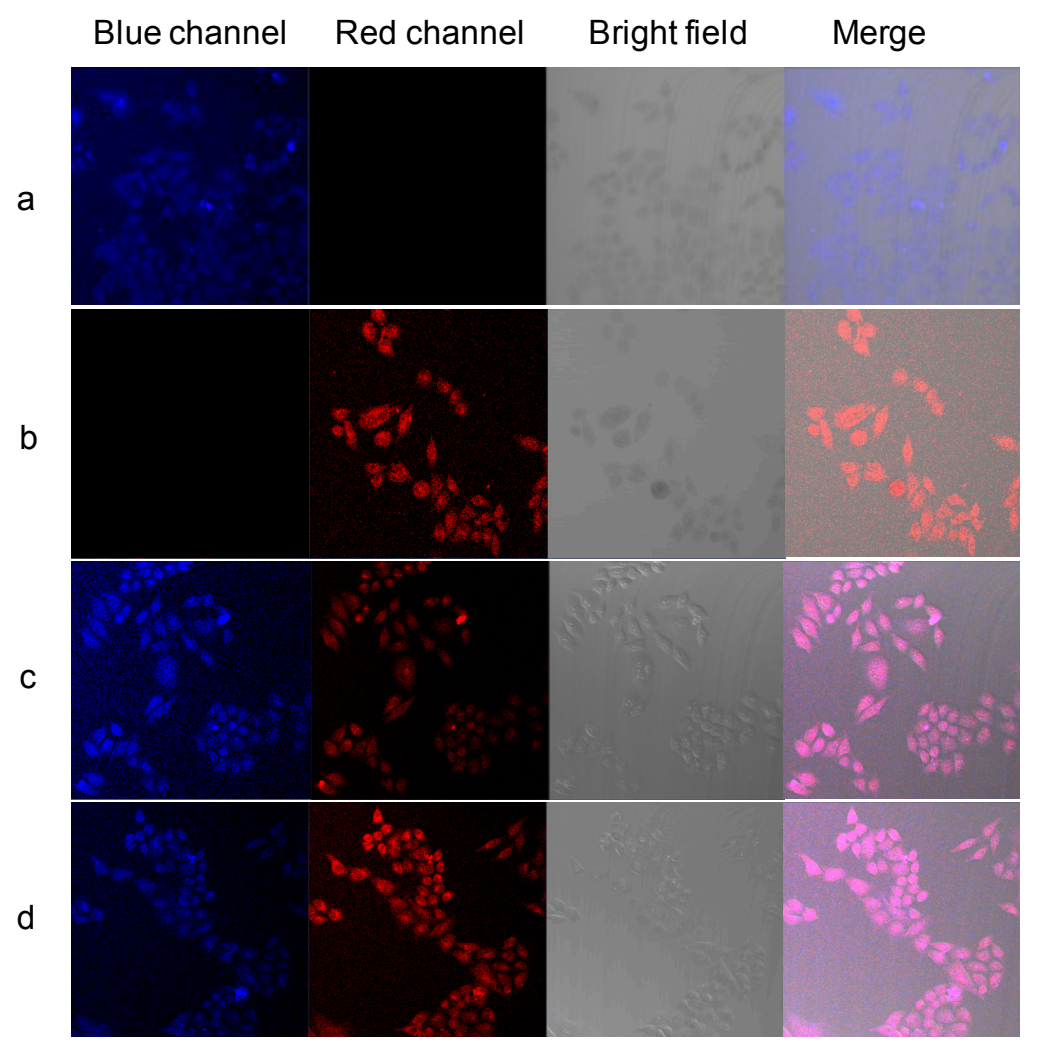

Figure 3. Fluorescent images of HeLa cells incubated with different polymers: (a) incubated with $\mathrm{P}_{\mathrm{NB}}$; (b) incubated with $\mathrm{P}_{\mathrm{NmR}}$; and (c,d) incubated with $\mathrm{P}_{\mathrm{MIX}} ;(\mathbf{a}-\mathbf{c})$ were observed at $25{ }^{\circ} \mathrm{C}$ and $(\mathbf{d})$ was observed at $37^{\circ} \mathrm{C}$.

\section{Conclusions}

In summary, two fluorescent polymers, $\mathrm{P}_{\mathrm{NB}}$ and $\mathrm{P}_{\mathrm{NmR}}$, were prepared to form a novel energy-transfer thermometer for ratiometric temperature sensing. They exhibit different LCSTs because of the various thermo-responsive monomers. The temperature sensing system displayed good stability and biocompatibility. The intracellular temperature imaging of living cells by these ratiometric temperature sensing polymers was explored. It is expected that this LCSTs difference showing ratiometric fluorescence change would have a significant impact on the various applications, such as fluorescent temperature sensing and bio-imaging of biological processes at specific organelles.

Supplementary Materials: The following are available online at www.mdpi.com/xxx/s1, Figure S1: ${ }^{1} \mathrm{H}$ NMR of BOBPYOH, Figure S2: ${ }^{13} \mathrm{C}$ NMR of BOBPYOH, Figure S3: ${ }^{1} \mathrm{H}$ NMR of BOBPYOX, Figure S4: ${ }^{13} \mathrm{C}$ NMR of BOBPYOX. Figure S5: GPC result of $\mathrm{P}_{\mathrm{NB}}$, Figure S6: GPC result of $\mathrm{P}_{\mathrm{NmR}}$.

Acknowledgments: This work was financially supported by Macao Science and Technology Development Fund under Grant No. 052/2015/A2, 082/2016/A2, and the University of Macau research grants under grant Nos. MYRG2016-00058-FHS, MYRG2017-00066-FHS, and SRG2015-00007-FHS.

Author Contributions: Zhaoyang Ding and Xuanjun Zhang conceived and designed the experiments; Zhaoyang Ding, Chunfei Wang, and Gang Feng performed the experiments; and Zhaoyang Ding analyzed the data and wrote the paper.

Conflicts of Interest: The authors declare no conflict of interest.

\section{References}

1. Bai, T.; Gu, N. Micro/nanoscale thermometry for cellular thermal sensing. Small 2016, 12, 4590-4610. [CrossRef] [PubMed] 
2. Gota, C.; Okabe, K.; Funatsu, T.; Harada, Y.; Uchiyama, S. Hydrophilic fluorescent nanogel thermometer for intracellular thermometry. J. Am. Chem. Soc. 2009, 131, 2766-2767. [CrossRef] [PubMed]

3. Wang, X.-D.; Wolfbeis, O.S.; Meier, R.J. Luminescent probes and sensors for temperature. Chem. Soc. Rev. 2013, 42, 7834-7869. [CrossRef] [PubMed]

4. Uchiyama, S.; Gota, C. Luminescent molecular thermometers for the ratiometric sensing of intracellular temperature. Rev. Anal. Chem. 2017, 36. [CrossRef]

5. Zhou, J.; Mishra, K.; Bhagat, V.; Joy, A.; Becker, M.L. Thermoresponsive dual emission nanosensor based on quantum dots and dye labeled poly( $N$-isopropylacrylamide). Polym. Chem. 2015, 6, 2813-2816. [CrossRef]

6. Liu, Y.; Oda, H.; Inoue, Y.; Ishihara, K. Movement of a quantum dot covered with cytocompatible and PH-responsible phospholipid polymer chains under a cellular environment. Biomacromolecules 2016, 17, 3986-3994. [CrossRef] [PubMed]

7. $\mathrm{Hu}, \mathrm{X}$.; Li, Y.; Liu, T.; Zhang, G.; Liu, S. Intracellular cascade fret for temperature imaging of living cells with polymeric ratiometric fluorescent thermometers. ACS Appl. Mater. Interfaces 2015, 7, 15551-15560. [CrossRef] [PubMed]

8. $\quad$ Chen, Z.; Zhang, K.Y.; Tong, X.; Liu, Y.; Hu, C.; Liu, S.; Yu, Q.; Zhao, Q.; Huang, W. Phosphorescent polymeric thermometers for in vitro and in vivo temperature sensing with minimized background interference. Adv. Funct. Mater. 2016, 26, 4386-4396. [CrossRef]

9. Kim, J.H.; Jung, Y.; Lee, D.; Jang, W.D. Thermoresponsive polymer and fluorescent dye hybrids for tunable multicolor emission. Adv. Mater. 2016, 28, 3499-3503. [CrossRef] [PubMed]

10. Li, T.; He, S.; Qu, J.; Wu, H.; Wu, S.; Zhao, Z.; Qin, A.; Hu, R.; Tang, B.Z. Thermoresponsive aie polymers with fine-tuned response temperature. J. Mater. Chem. C 2016, 4, 2964-2970. [CrossRef]

11. Zhou, H.; Liu, F.; Wang, X.; Yan, H.; Song, J.; Ye, Q.; Tang, B.Z.; Xu, J. Aggregation induced emission based fluorescence $\mathrm{PH}$ and temperature sensors: Probing polymer interactions in poly( $N$-isopropyl acrylamide-co-tetra(phenyl)ethene acrylate)/poly(methacrylic acid) interpenetrating polymer networks. J. Mater. Chem. C 2015, 3, 5490-5498. [CrossRef]

12. Maji, S.; Cesur, B.; Zhang, Z.; De Geest, B.G.; Hoogenboom, R. Poly(N-isopropylacrylamide) coated gold nanoparticles as colourimetric temperature and salt sensors. Polym. Chem. 2016, 7, 1705-1710. [CrossRef]

13. Hu, X.; Zhang, Y.; Xie, Z.; Jing, X.; Bellotti, A.; Gu, Z. Stimuli-responsive polymersomes for biomedical applications. Biomacromolecules 2017, 18, 649-673. [CrossRef] [PubMed]

14. Thambi, T.; Phan, V.H.; Lee, D.S. Stimuli-sensitive injectable hydrogels based on polysaccharides and their biomedical applications. Macromol. Rapid Commun. 2016, 37, 1881-1896. [CrossRef] [PubMed]

15. Ding, Z.; Cao, X. Affinity precipitation of cellulase using PH-response polymer with cibacron blue F3GA. Sep. Purif. Technol. 2013, 102, 136-141. [CrossRef]

16. Ding, Z.; Cao, X. Affinity precipitation of human serum albumin using a thermo-response polymer with an L-thyroxin ligand. BMC Biotechnol. 2013, 13, 109. [CrossRef] [PubMed]

17. Ding, Z.; Kang, L.; Liu, J.; Zhang, X.; Cao, X. Preparation of PH-responsive metal chelate affinity polymer for adsorption and desorption of insulin. J. Chem. Technol. Biotechnol. 2017, 92, 1590-1595. [CrossRef]

18. Lyon, L.A.; Meng, Z.; Singh, N.; Sorrell, C.D.; St John, A. Thermoresponsive microgel-based materials. Chem. Soc. Rev. 2009, 38, 865-874. [CrossRef] [PubMed]

19. Weber, C.; Hoogenboom, R.; Schubert, U.S. Temperature responsive bio-compatible polymers based on poly(ethylene oxide) and poly(2-oxazoline)s. Prog. Polym. Sci. 2012, 37, 686-714. [CrossRef]

20. Wei, M.; Gao, Y.; Li, X.; Serpe, M.J. Stimuli-responsive polymers and their applications. Polym. Chem. 2017, 8, 127-143. [CrossRef]

21. Roy, D.; Brooks, W.L.A.; Sumerlin, B.S. New directions in thermoresponsive polymers. Chem. Soc. Rev. 2013, 42, 7214-7243. [CrossRef] [PubMed]

22. Ma, H.; Qi, C.; Cheng, C.; Yang, Z.; Cao, H.; Yang, Z.; Tong, J.; Yao, X.; Lei, Z. Aie-active tetraphenylethylene cross-linked $\mathrm{N}$-isopropylacrylamide polymer: A long-term fluorescent cellular tracker. ACS Appl. Mater. Interfaces 2016, 8, 8341-8348. [CrossRef] [PubMed]

23. Yamada, A.; Hiruta, Y.; Wang, J.; Ayano, E.; Kanazawa, H. Design of environmentally responsive fluorescent polymer probes for cellular imaging. Biomacromolecules 2015, 16, 2356-2362. [CrossRef] [PubMed]

24. Lee, S.H.; Bui, H.T.; Vales, T.P.; Cho, S.; Kim, H.-J. Multi-color fluorescence of pnipam-based nanogels modulated by dual stimuli-responsive fret processes. Dyes Pigm. 2017, 145, 216-221. [CrossRef] 
25. Qiao, J.; Hwang, Y.-H.; Chen, C.-F.; Qi, L.; Dong, P.; Mu, X.-Y.; Kim, D.-P. Ratiometric fluorescent polymeric thermometer for thermogenesis investigation in living cells. Anal. Chem. 2015, 87, 10535-10541. [CrossRef] [PubMed]

26. Chen, C.Y.; Chen, C.T. A pnipam-based fluorescent nanothermometer with ratiometric readout. Chem. Commun. 2011, 47, 994-996. [CrossRef] [PubMed]

27. Yin, J.; Li, C.; Wang, D.; Liu, S. Fret-derived ratiometric fluorescent $\mathrm{k}^{+}$sensors fabricated from thermoresponsive poly( $N$-isopropylacrylamide) microgels labeled with crown ether moieties. J. Phys. Chem. B 2010, 114, 12213-12220. [CrossRef] [PubMed]

28. Hu, J.; Liu, S. Responsive polymers for detection and sensing applications: Current status and future developments. Macromolecules 2010, 43, 8315-8330. [CrossRef]

29. Iwai, K.; Matsumura, Y.; Uchiyama, S.; de Silva, A.P. Development of fluorescent microgel thermometers based on thermo-responsive polymers and their modulation of sensitivity range. J. Mater. Chem. 2005, 15, 2796-2800. [CrossRef]

30. Bonnett, R.; McManus, K.A. Approaches to the stepwise synthesis of benzoporphyrins and phthalocyanines. Part 1. Synthesis of opp-dibenzoporphyrins (dibenzo $[g, q]$ porphyrins). J. Chem. Soc. Perkin Trans. 1 1996, 2461-2466. [CrossRef]

31. Diana, P.; Martorana, A.; Barraja, P.; Montalbano, A.; Carbone, A.; Cirrincione, G. Nucleophilic substitutions in the isoindole series as a valuable tool to synthesize derivatives with antitumor activity. Tetrahedron 2011, 67, 2072-2080. [CrossRef]

32. Chen, N.; Zhang, W.; Chen, S.; Wu, Q.; Yu, C.; Wei, Y.; Xu, Y.; Hao, E.; Jiao, L. Sterically protected $\mathrm{N}_{2} \mathrm{O}$-type benzopyrromethene boron complexes from boronic acids with intense red/near-infrared fluorescence. Org. Lett. 2017, 19, 2026-2029. [CrossRef] [PubMed]

33. Zhou, B.; Ma, P.; Chen, H.; Wang, C. Amine-accelerated manganese-catalyzed aromatic C-H conjugate addition to $\alpha, \beta$-unsaturated carbonyls. Chem. Commun. 2014, 50, 14558-14561. [CrossRef] [PubMed]

34. Ding, Z.; Zheng, X.; Li, S.; Cao, X. Immobilization of cellulase onto a recyclable thermo-responsive polymer as bioconjugate. J. Mol. Catal. B Enzym. 2016, 128, 39-45. [CrossRef]

(C) 2018 by the authors. Licensee MDPI, Basel, Switzerland. This article is an open access article distributed under the terms and conditions of the Creative Commons Attribution (CC BY) license (http:/ / creativecommons.org/licenses/by/4.0/). 